\section{Nesting patterns of some terrestrial birds in Danta Forest Range, northern Gujarat, India}

\author{
Nikunj Gajera ${ }^{1}$, S.M. Dave ${ }^{2} \&$ N.A. Dharaiya ${ }^{3}$ \\ ${ }^{1-3}$ Department of Life Sciences, Hemchandracharya North Gujarat \\ University, Patan, Gujarat 384265, India \\ Email: ${ }^{1}$ gajeranikunj@gmail.com; ${ }^{3}$ adinishi@gmail.com
}

The nesting of terrestrial birds in Gujarat has not been documented in detail, and information for northern Gujarat $\left(71^{\circ} 59^{\prime}-73^{\circ} 58^{\prime} \mathrm{E} \& 23^{\circ} 26^{\prime}-24^{\circ} 39^{\prime} \mathrm{N}\right)$ is especially scattered. The few reports that exist (Ali 1945; Abdulali 1962; Himmatsinhji 1968; Parasharya 1984; Pailmes \& Briggs 1986) are chiefly related to population and distribution of wetland birds in Gujarat. Barring a few observations on nesting of terrestrial birds (e.g., Soni et al. 2004 in Rajkot city), there are no reported attempts to study their nesting patterns in northern Gujarat In fact, there is no detailed checklist of the region's avifauna. We present in this paper a concise account of our observations on distribution and nesting patterns of the terrestrial birds in Danta Forest Range in northern Gujarat.

\section{Study Area}

The Danta Forest Range is located between $24^{\circ} 1$ '24"'$24^{\circ} 37^{\prime} 30^{\prime \prime} \mathrm{N} \& 72^{\circ} 15^{\prime} 45^{\prime \prime}-73^{\circ} 1^{\prime} 30^{\prime \prime} \mathrm{E}$ in Danta taluka in Banaskantha district of Gujarat (Fig. 1). The fact that the Danta FR is situated at the tail end of the Aravalli range and connects both the Jessore and Balaram Ambaji wildlife sanctuaries makes it an important site for long-term conservation of the region's wildlife. The dry deciduous and thorn forest (Sub type: $5 \mathrm{~A} / \mathrm{C}_{3}$ Southern Dry Mixed Deciduous Forest of Champion \& Seth 1968) is spread over 47,941ha with hilly terrain and characterized by steep slopes. Most of the rivers are annual, originating from the Aravalli hills especially the Abu mountain. Notable among them are Banas, Sirinala, Arjuni, Saraswati, and Selvani. According to the biogeographic

Date of publication 26 March 2009

ISSN 0974-7907 (online) | 0974-7893 (print)

Editor: Rajah Jayapa

Manuscript details:

Ms \# 01757

Received 07 April 2007

Final received 05 January 2009

Finally accepted 13 January 2009

Citation: Gajera, N., S.M. Dave \& N.A. Dharaiya (2009). Nesting patterns of some terrestrial birds in Danta Forest Range, northern Gujarat, India. Journal of Threatened Taxa 1(3): 170-173.

Copyright: (C) Nikunj Gajera, S.M. Dave \& N.A. Dharaiya 2009. Creative Commons Attribution 3.0 Unported License. JoTT allows unrestricted use of this article in any medium for non-profit purposes, reproduction and distribution by providing adequate credit to the authors and the source of publication.

Acknowledgement: One of the authors is thankful to the Director, Gujarat Forest Research Institute, Gandhinagar for financial assistance. Thanks are also due to the Range Forest Officer, Danta Range for permission and all necessary help during the fieldwork.

OPEN ACGESS I FREE DOWNLOAD classification of Rodgers \& Panwar (1988), the forest range of Danta hills falls under the Aravalli biogeographic region of Province $4 \mathrm{~B}$ of Gujarat Rajwara in the

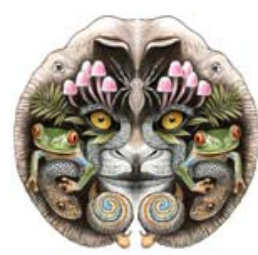
semi-arid zone.

The climate is typically tropical with three main seasons. Summer ranges from March to June (with mean maximum temperature of $40^{\circ} \mathrm{C}$ ), followed by a rainy season heralded by the south-west monsoon between July and September. The cold season starts in December and may last until February, with a mean minimum temperature of $9^{\circ} \mathrm{C}$. May is the hottest month and January is the coldest; relative humidity during the monsoon may range from $60 \%$ to $85 \%$.

\section{Methods}

Fieldwork was carried out during the summer (i.e. MarchJune) 2006, when most land birds breed. Birds were observed using a pair of 10 x 50 binoculars, and were identified using standard field guides, e.g. 'The Book of Indian Birds' (Ali 1996). Nests were located and data on nest characteristics and nestsites were collected using established methodologies (Soni et al. 2004). The plant species on which nests were placed were also identified and recorded.

\section{Results and Discussion}

In total, 103 terrestrial bird species belonging to 30 families were recorded during the study period (Table 1). Of these, 31 species belonging to 16 families were observed nesting in the area (Table 2, 3). In total, 101 nests were recorded during the study period (Fig. 2). The highest number of nests were made by Baya Weavers (16), followed by House Crows (14) and Green Bee-eaters (12). Thirty-seven nests were of hole-nesting birds, while the remaining were of non-hole nesters. Baya Weaver nests were observed mainly along streams and around check dams. Green Bee-eaters made their nests on roadside burrows, allowing for easy observation and recorded during fieldwork.

Table 4 lists nest host plant species. Of the 13 tree species recorded, Azadirachta indica was found to be used by four bird species, while Celastrus paniculatus, Butea monosperma and Acacia nilotica were each used by three species. A preliminary analysis of host-plant characteristics showed that tree species with either thorny branches or large, dense canopies were preferred by birds for placing their nests. Among the grasses and sedges, Pennisetum typhoides and Typha angustifolia were the predominant hosts of Plain Prinia and Black-breasted Weaver, respectively. Bank Myna, which usually nest in burrows excavated in earthcuttings, were often observed to appropriate old nests of Common Mynas placed in tree-holes.

With respect to nest location, 18 bird species were found nesting near human habitation and 13 species near water sources, while seven species were observed nesting near the road (Fig. 3). It was also found that 16 species placed their nests on trees and five were using tree-holes; in addition, five species were nesting in earth-burrows and two species built mud-nests either on rock crevices or on the wall just under the eaves of buildings. Rose-ringed Parakeet were observed nesting in both natural tree holes and crevices on walls of buildings. Nests of Blue Rock Pigeon and Rose-ringed Parakeet were generally found in human settlements, showing their association with humans. In general, the nesting behaviour of 
Table 1. Checklist of birds recorded in the Danta Forest Range with their residential status

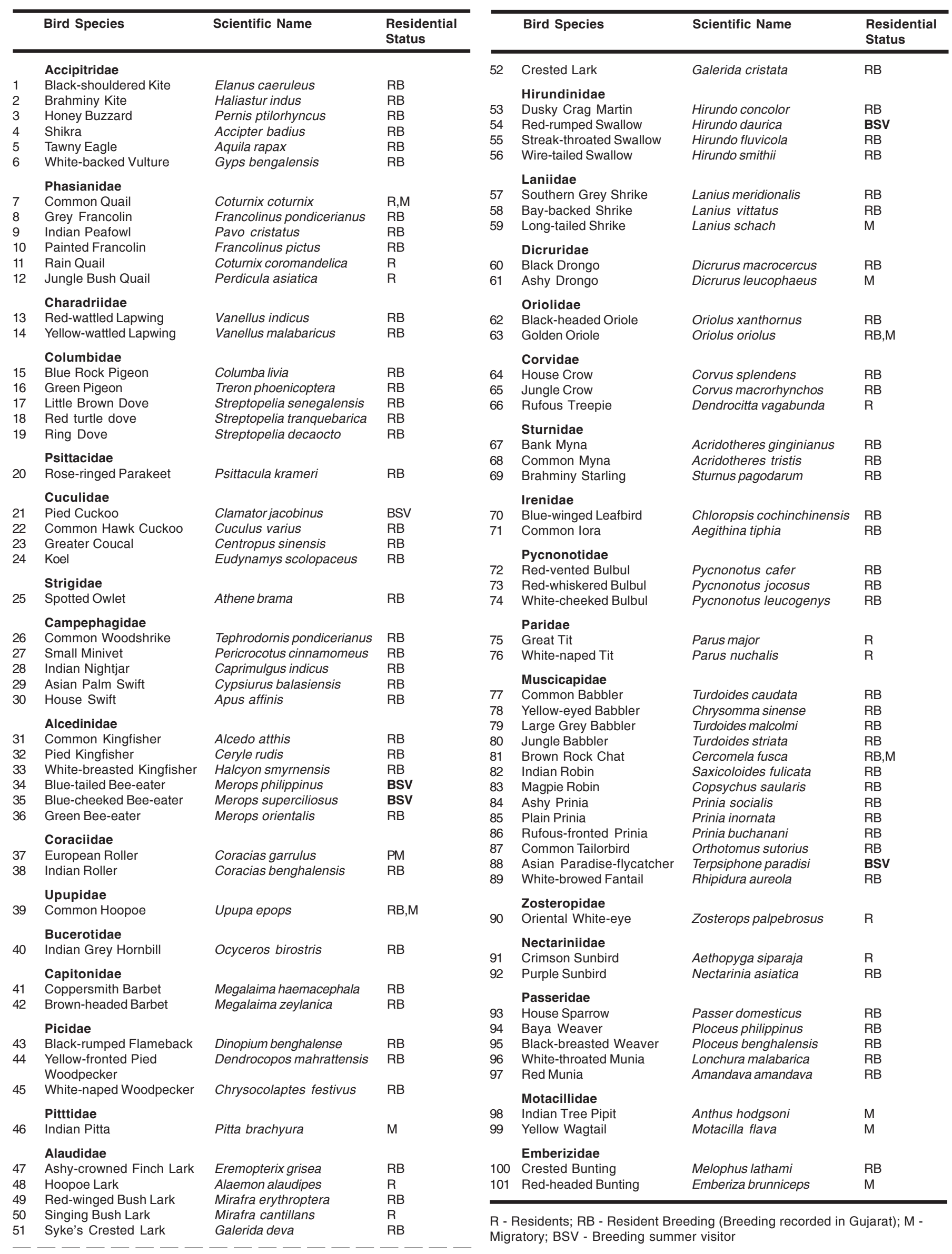


Table 2. Number of bird species recorded per family

\begin{tabular}{|c|c|c|c|c|c|}
\hline & Family & \# Species Recorded & & Family & \# Species Recorded \\
\hline 1 & Accipitridae & 6 & 17 & Hirundinidae & 4 \\
\hline 2 & Phasianidae & 7 & 18 & Laniidae & 3 \\
\hline 3 & Charadriidae & 2 & 19 & Dicruridae & 2 \\
\hline 4 & Columbidae & 5 & 20 & Oriolidae & 2 \\
\hline 5 & Psittacidae & 1 & 21 & Corvidae & 3 \\
\hline 6 & Cuculidae & 4 & 22 & Sturnidae & 3 \\
\hline 7 & Strigidae & 1 & 23 & Irenidae & 2 \\
\hline 8 & Campephagidae & 5 & 24 & Pycnonotidae & 3 \\
\hline 9 & Alcedinidae & 6 & 25 & Paridae & 2 \\
\hline 10 & Coraciidae & 2 & 26 & Muscicapidae & 13 \\
\hline 11 & Upupidae & 1 & 27 & Zosteropidae & 1 \\
\hline 12 & Bucerotidae & 1 & 28 & Nectariniidae & 2 \\
\hline 13 & Capitonidae & 2 & 29 & Passeridae & 5 \\
\hline 14 & Picidae & 3 & 30 & Motacillidae & 2 \\
\hline 15 & Pitttidae & 1 & 31 & Emberizidae & 2 \\
\hline 16 & Alaudidae & 6 & & & \\
\hline
\end{tabular}

Table 3. List of nesting bird species, number of nests and nest type observed

\begin{tabular}{|c|c|c|c|c|c|}
\hline & Bird Species & Scientific Name & \# Nest & Non-Hole Nest & Hole Nest \\
\hline & Charadriidae & & & & \\
\hline 1 & $\begin{array}{l}\text { Red-wattled Lapwing } \\
\text { Columbidae }\end{array}$ & Vanellus indicus & 1 & + & \\
\hline 2 & Blue Rock Pigeon & Columba livia & 3 & + & \\
\hline 3 & $\begin{array}{l}\text { Ring Dove } \\
\text { Psittacidae }\end{array}$ & Streptopelia decaocto & 2 & + & \\
\hline 4 & $\begin{array}{l}\text { Rose-ringed Parakeet } \\
\text { Strigidae }\end{array}$ & Psittacula krameri & 2 & & + \\
\hline 5 & $\begin{array}{l}\text { Spotted Owlet } \\
\text { Campephagidae }\end{array}$ & Athene brama & 1 & & + \\
\hline 6 & $\begin{array}{l}\text { Small Minivet } \\
\text { Alcedinidae }\end{array}$ & Pericrocotus cinnamomeus & 1 & + & \\
\hline 7 & White-breasted Kingfisher & Halcyon smyrnensis & 4 & & + \\
\hline 8 & Blue-cheeked Bee-eater & Merops superciliosus & 8 & & + \\
\hline 9 & $\begin{array}{l}\text { Green Bee-eater } \\
\text { Picidae }\end{array}$ & Merops orientalis & 12 & & + \\
\hline 10 & $\begin{array}{l}\text { Black-rumped Flameback } \\
\text { Hirundinidae }\end{array}$ & Dinopium benghalense & 1 & & + \\
\hline 11 & Red-rumped Swallow & Hirundo daurica & 3 & + & \\
\hline 12 & $\begin{array}{l}\text { Wire-tailed Swallow } \\
\text { Laniidae }\end{array}$ & Hirundo smithii & 2 & + & \\
\hline 13 & $\begin{array}{l}\text { Bay-backed Shrike } \\
\text { Dicruridae }\end{array}$ & Lanius vittatus & 1 & + & \\
\hline 14 & $\begin{array}{l}\text { Black Drongo } \\
\text { Oriolidae }\end{array}$ & Dicrurus adsimilis & 1 & + & \\
\hline 15 & $\begin{array}{l}\text { Golden Oriole } \\
\text { Corvidae }\end{array}$ & Oriolus oriolus & 1 & + & \\
\hline 16 & $\begin{array}{l}\text { House Crow } \\
\text { Sturnidae }\end{array}$ & Corvus splendens & 14 & + & \\
\hline 17 & Bank Myna & Acridotheres ginginianus & 2 & & + \\
\hline 18 & Common Myna & Acridotheres tristis & 1 & & + \\
\hline 19 & $\begin{array}{l}\text { Brahminy Starling } \\
\text { Pycnonotidae }\end{array}$ & Sturnus pagodarum & 3 & & + \\
\hline 20 & $\begin{array}{l}\text { Red-vented Bulbul } \\
\text { Muscicapidae }\end{array}$ & Pycnonotus cafer & 4 & + & \\
\hline 21 & Common Babbler & Turdoides caudata & 2 & + & \\
\hline 22 & $\begin{array}{l}\text { Large Grey Babbler } \\
\text { Muscicapidae }\end{array}$ & Turdoides malcolmi & 1 & + & \\
\hline 23 & Asian Paradise-flycatcher & Terpsiphone paradisi & 1 & + & \\
\hline 24 & Indian Robin & Saxicoloides fulicata & 2 & & + \\
\hline 25 & Magpie Robin & Copsychus saularis & 1 & & + \\
\hline 26 & Plain Prinia & Prinia inornata & 1 & + & \\
\hline 27 & $\begin{array}{l}\text { Common Tailorbird } \\
\text { Nectariniidae }\end{array}$ & Orthotomus sutorius & 3 & + & \\
\hline 28 & $\begin{array}{l}\text { Purple Sunbird } \\
\text { Passeridae }\end{array}$ & Nectarinia asiatica & 4 & + & \\
\hline 29 & Baya Weaver & Ploceus philippinus & 16 & + & \\
\hline 30 & Black-breasted Weaver & Ploceus benghalensis & 5 & + & \\
\hline \multirow[t]{2}{*}{31} & White-throated Munia & Lonchura malabarica & 3 & + & \\
\hline & & Total & 101 & $+=20$ & $+=11$ \\
\hline
\end{tabular}

+ - Present 
Table 4. Nesting of different bird species observed on various trees

\begin{tabular}{llcl}
\hline & Tree species & \# bird species & Bird species nesting \\
\hline 1 & Azadirachta indica (Limdo) & 4 & Common Myna, Blue Rock Pigeon, White-throated Munia, Small Minivet \\
2 & Derris indica (Karanj) & 1 & Golden Oriole \\
3 & Ficus benghalensis (Vadalo) & 2 & Ring Dove, Large Grey Babbler \\
4 & Syzygium cumini (Jambu) & 1 & Common Babbler \\
5 & Adhatoda vasica (Araduso) & 2 & House Crow, Rose-ringed Parakeet \\
6 & Terminalia catappa (Badam) & 1 & Common Tailorbird \\
7 & Celastrus paniculatus (Kanaji) & 3 & Brahminy Myna, Spotted Owlet \\
8 & Butea monosperma (Khakharo) & 3 & Bay-backed Shrike, Black-rumped Flameback, Black Drongo \\
9 & Acacia farnesiana (Talbaval) & 2 & Purple Sunbird, Common Babbler \\
10 & Acacia nilotica (Rambaval) & 3 & Red-vented Bulbul, Paradise Flycatcher, White-throated Munia \\
11 & Prosopis juliflora (Gandobaval) & 1 & Plain Prinia \\
12 & Pennisetum typhoides (Bajaro) & 1 & Black-breasted Weaver \\
13 & Typha angustifolia & 1 & \\
\hline
\end{tabular}

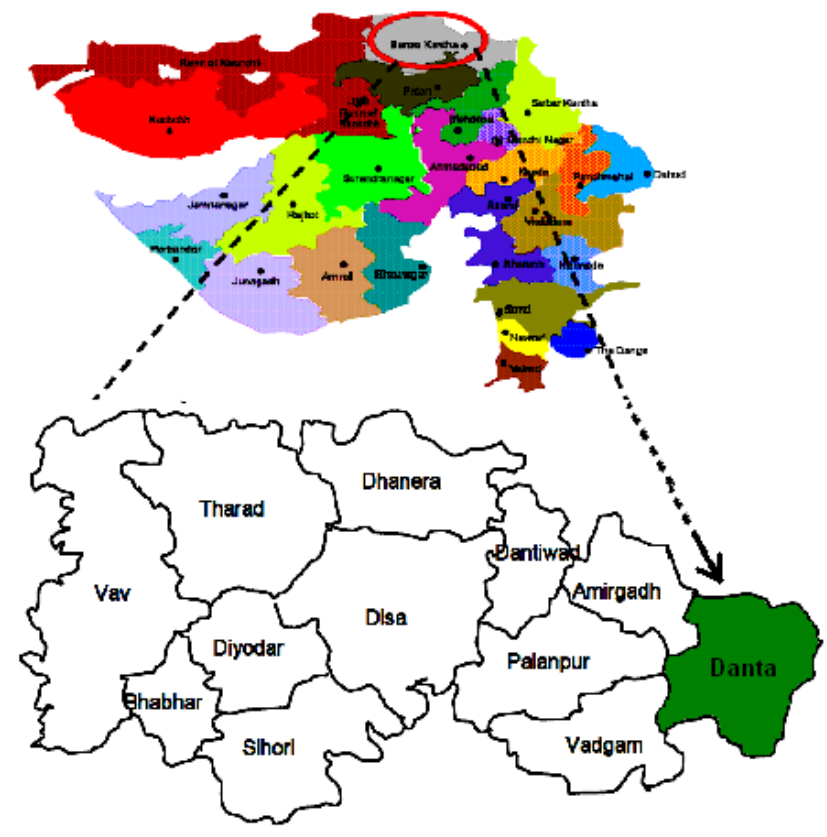

Figure 1. Study area: Danta Taluka of Banaskantha district, Gujarat

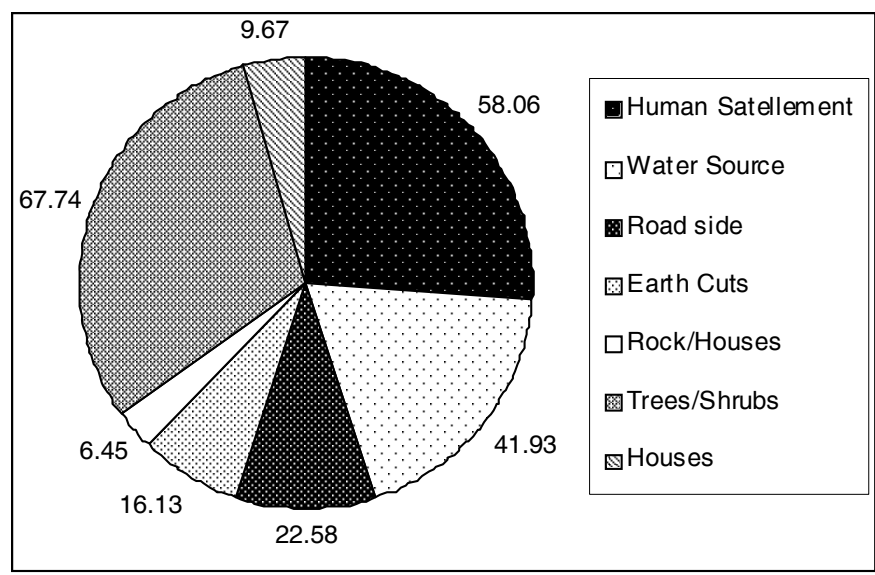

Figure 3. Proportion of nesting sites as observed among the breeding birds of Danta Forest Range, Gujarat $(n=31)$

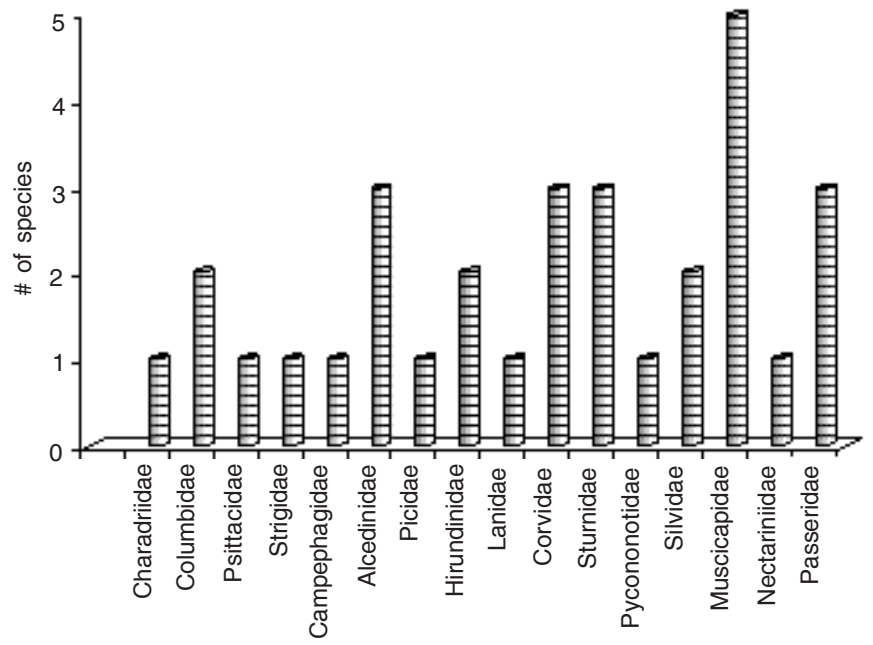

Figure 2. Family-wise number of species nesting in the Danta Forest Range, Gujarat

the birds in the Danta FR indicates that most of the terrestrial birds prefer either large canopy trees or thorny bushes for nesting, probably to avoid predation.

\section{References}

Abdulali, H. (1962). An ornithological trip to the Gulf of Kutch. Journal of Bombay Natural History Society 59: 655-658.

Ali, S. (1945). The Birds of Kutch. Oxford University Press, Bombay, $190 \mathrm{pp}$.

Ali, S. (1996). The Book of Indian Birds. Bombay Natural History Society, Bombay, 354pp.

Himmatsinhji, M.K. (1968). Some interesting migrants in the Kutch. Journal of Bombay Natural History Society 65: 225

Palmes, P. \& C. Briggs (1986). Crab-plovers Dromas ardeola in the Gulf of Kutch. Forktail 1: 21-22.

Parasharya, B.M. (1984). Studies on the coastal birds and their marine habitat with special emphasis on the biology of the Indian Reef Heron Egretta gularis. Ph.D. Thesis submitted to Saurashtra University, Rajkot (unpublished).

Rodgers, W.A. \& H.S. Panwar. (1988). Planning a Wildlife Protected Area Network in India. Vol-1. The Report. Wildlife Institute of India, Dehra Dun.

Soni, V.C., P. Sharma, S.M. Dave, K. Bhalodia \& V. Vijaykumar (2004). Nesting ecology of some terrestrial birds in Rajkot city (Gujarat). Journal of Current Bioscience 2(1): 97-104. 